\title{
REMOVAL OF SOME HEAVY METALS AND \\ POLLUTED ANTIBACTERIAL ACTIVITIES VIA SYNTHESIZED MAGNETIC NANO-COMPOSITE OF IRON OXIDE AND DERIVATIVES: CHEMICAL AND MICROBIAL TREATMENT CASE STUDY: AL TARD- BILRAHA DRAIN ISMAILIA, EGYPT
}

\author{
Abdulhady, Yasser A.M. ${ }^{*}$ and Mona M. El-Shazly ${ }^{2}$ \\ ${ }^{1}$ Water Treatment and Desalination Unit, Department of \\ Hydrogeochemistry, Desert Research Center, El-Matareya, \\ Cairo,Egypt \\ ${ }^{2}$ Department of Soil Fertility and Microbiology, Desert Research \\ Center, El-Matareya, Cairo, Egypt \\ *E-mail address: Yasser_vip6@hotmail.com
}

$\mathrm{F}$ or preparation of nano-composite (iron oxide nanoparticles coated by $\mathrm{TiO}_{2}$ ) sol-gel method was used. The difference between iron oxide nanoparticles and iron oxide nanoparticles coated by $\mathrm{TiO}_{2}$, which had an antibacterial effect and ability to remove heavy metals was discussed. The nano-sized particles of prepared metal nanoparticles were about 55-65 nm for the two types. Different characterization instruments such as X-ray diffraction (XRD) analysis; scanning electron microscopy (SEM), FT-IR, particle size analyzer and VSM were used to know the magnetic properties of prepared nano-composites. The antibacterial effect of two types of nano-composite were investigated against pathogenic bacteria, which illustrated that nanoparticles had moderate antibacterial activity against both gram-positive and gram negative pathogenic bacterial strains, maintains pharmaceutical and biomedical industries application. High reduction percent of antibacterial activity was shown after $30 \mathrm{~min}$ by $150 \mu \mathrm{g} / \mathrm{ml}$ of nanoparticles prepared. Also, the elevated inhibition percent was obtained due to removal of aluminum and iron ions from poisoned water and decreasing effect of COD and BOD concentrations with reducing total nitrogen percent.

Keywords: magnetic nanoparticles, iron oxide coated by $\mathrm{TiO}_{2}$ nanoparticles, antibacterial activities, co-precipitation, E. coli

Synthesize nano-sized inorganic and organic particles made a breakthrough in various applications in industry, medicine, therapeutics, synthetic textiles, water treatment and food wrapping products (Feynman, 
1991). Small size and high surface to volume ratio of nanoparticles increase their interaction with the bacteria that leading to a large antibacterial activities. Metal nanoparticles with antibacterial activity had merged with coated on to surfaces can offer great applications (Gutierrez et al., 2010). The composites prepared using metal nanoparticles and polymers can find better utilization due to the enhanced antimicrobial activity. The role of iron oxide with titanium nanoparticles had potential antimicrobials and the possible mechanism of their inhibitory actions. Metal nanoparticles have far reaching industrial and medical application, due to their unique physicochemical and biological properties. The nano-composites synthesize with polymers can be of best use, because of enhanced antibacterial activity (Woo et al., 2004 and Laurent et al., 2008). Metal nanoparticles have far reaching industrial and medical applications, due to their exclusive physicochemical and biological properties. Although the influence of the extended exposure to nanoparticles on human health and environment is not yet fully known, which leads to the need for thorough studies before their large-scale production and application in various fields (Kolar et al., 2001; El Saesser and Howard, 2010 and Chorianopoulos et al., 2011). Antibacterial agents had a concern worldwide of microbial treatment from various sources to solve this problem (Gajjar et al., 2009). Iron oxide nanoparticles with composites gave a synthesizing technology for new antibacterial agents and also, reducing bio-film development (Fujishima and Honda, 1972). The surface area of the nanoparticles attached with bacteria accounts for its antibacterial activity. Metal nanoparticles can affect the biological behavior on organ, tissue, cellular, sub-cellular, and protein levels. The size of the nanoparticles is small and these can easily access the skin, lungs, and brain and cause adverse effects (Fujishima et al., 1992; Wei et al., 1994 and Pham et al., 1995). Metal nanoparticles are promising as antibacterial and therapeutic agents due to their biological and physiochemical properties. Synthesis of iron oxide nanoparticles with different metal oxides had been greatly elevating, because of its large technological and biomedical applications (Asharani et al., 2008). Iron oxide nanoparticles have smart properties that had a multivalent oxidation states, which made them of great interest, also their super paramagnetic and high electro-static attraction with large magnetic susceptibility (Shaw et al., 2008 and Schrand et al., 2010). Interaction between iron oxide nanoparticles with air, water and soil in the environment might be several changes in a surface characteristic that made changes of particle charge and other surface properties (Mahdavi et al., 2007). In the recent times, nanotechnology has brought the nanosized inorganic and organic particles, which are finding increasing applications as amendments in industrial, medicine and therapeutics, synthetic textiles and food packaging products (Ireland et al., 1993). Ranging of nanoparticles usually in dimension from 1-100 nanometers (nm) have properties unique from their bulk equivalent. Decreasing in the dimensions of the materials to

Egyptian J. Desert Res., 68, No. 1, 15-36 (2018) 
the atomic level, changes their properties. Moreover, as the biological processes also occur at the nanoscale and due to their amenability to biological functionalization, the nanoparticles are finding important applications in the field of medicine (Matsunaga et al., 1998). Currently, the metallic nanoparticles are thoroughly being explored and extensively investigated as potential antimicrobials. The antimicrobial activity of the nanoparticles is known to be a function of the surface area in contact with the microorganisms. The small size and the high surface to volume ratio, i.e. large surface area of the nanoparticles enhance their interaction with the microbes to carry out a broad range of probable antimicrobial activities. Metal nanoparticles with antimicrobial activity, when embedded and coatedon to surfaces can find immense applications in water treatment (Matsungaet al., 2005). This study aim to synthesize iron-oxide nanoparticles coated by titanium dioxide using sol-gel method and characterization different instruments, and also aimed to evaluate the reduction percent of prepared nanoparticles in removal of heavy metals from polluted water. This study is concentrated on the various synthetic routes of iron nanoparticles and their antimicrobial activity dependant on various factors; like shape of the particles surfactants, used plant mediated biosynthesis of nanoparticles have been of recent interest for the researchers to exploit the wasted or recycled biomass for the synthetic application (Xiao et al., 2011, Laurent et al., 2011and Mahmoudi et al., 2011) and microorganisms (Kievit and Zhang et al.,2011 and Montferrand et al., 2013) the ultimate effect of the nano-sized material is to be employed in fabrication of antimicrobial patch. In the present study, an attempt has been made to synthesized iron-oxide nanoparticles in sol-gel method and characterizes it by particle size analyzer (PD), X-ray diffraction (XRD), and scanning electron microscope (SEM) along with the evaluation of their antibacterial activity of gram-positive and gram-negative bacteria. Iron oxide nanoparticles have been of great interest, not only for fundamental properties caused by their multivalent oxidation states, but also for their super paramagnetic, high force, low Curie temperature and high magnetic susceptibility.

\section{MATERIALS AND METHODS}

\section{Collection of Five Samples of Al Tard-Bilraha Drain Ismailia, Egypt Wastewater for Different Location}

Ferric chloride hexahydrate $\left(\mathrm{FeCl}_{3} .6 \mathrm{H}_{2} \mathrm{O}\right)$, ferrous chloride tetrahydrate $\left(\mathrm{FeCl}_{2} .4 \mathrm{H}_{2} \mathrm{O}\right)$ and ammonium hydroxide $\left(\mathrm{NH}_{4} \mathrm{OH}\right)$ were purchased from Merck. All acids used were of the highest purity available were obtained from Merck. $\mathrm{TiO}_{2}$ was obtained from titanium (IV) isopropoxide (TTIP) and dissolved in absolute ethanol and distilled water was added to the solution. 


\section{Preparation of Iron Nano-composite with $\mathrm{Coated}_{\mathrm{TiO}_{2}}$ \\ 2.1. Sol-gel method}

Sol-gel method is generally used to coat titanium dioxide on a magnetic core, followed by a heat treatment process to transform the initial amorphous phase into a photo-catalytic crystal structure (normally anatase). It typically involves the hydrolysis of one titanium alkyloxide precursor (like titanium isopropoxide in the presence of magnetic particles. This procedure is favorable for producing particles with excellent chemical homogeneity, high purity and more uniform phase distributions in multi-component systems. Sol gel processing route is a wet chemical process for the synthesis of colloidal dispersion of inorganic and organic inorganic hybrid materials. The synthesis of metal oxides by sol-gel synthesis has proven extremely versatile since it allows the formation of a large variety of metal oxides at relatively low temperatures via the processing of metal salt or metal alkoxide precursors. The structure and composition of nano-oxides formed by sol-gel method depend on the preparation condition, the nature of the precursors, the ion source and $\mathrm{pH}$. The Sol-gel synthesis of iron oxide particles was carried out from condensed ferric hydroxide gels, obtained from $\mathrm{FeCl}_{3}$ solutions in $\mathrm{NaOH}$. After aging the gel at $100^{\circ} \mathrm{C}$, mono-disperse pseudo-cubic $\alpha$ $\mathrm{Fe}_{2} \mathrm{O}_{3}$ particles were obtained (Sugimoto and Sakata 1992 and Sugimoto et al., 1993). The reaction proceeded through a two-step phase transformation from precipitated $\mathrm{Fe}(\mathrm{OH})_{3}$ gel to a fibrous $\beta-\mathrm{FeOOH}$ and finally to $\alpha-\mathrm{Fe}_{2} \mathrm{O}_{3}$. The magnetic nanoparticles (MNPs) were prepared according to Hong et al. (2006) and Indira and Lakshmi (2010). Briefly, $\mathrm{FeCl}_{2} .4 \mathrm{H}_{2} \mathrm{O}$ and $\mathrm{FeCl}_{3} .6 \mathrm{H}_{2} \mathrm{O}$ (molar ratio of $\mathrm{Fe}_{3}+\mathrm{Fe}_{2}=2 / 1$ ) were mixed with corresponding volume of TTIP, then isopropanol was added in beaker with vigorous stirring at 500 rpm at 80 。C.

\subsection{Characterization of iron oxide nano-composite}

XRD pattern of iron oxide nano-composite obtained using a X-ray diffractometer Schimadzu model: A PAN analytical X-rays diffraction equipment model Expert PRO with secondary mono-chromator, Curadiation $(\lambda=1.54 \mathrm{~A} 0)$ at $50 \mathrm{k} . \mathrm{v} .40 \mathrm{M} . \mathrm{A}$ and scanning speed $0.02_{\mathrm{o}} / \mathrm{sec}$. The micrographs of prepared particles were obtained using a Scanning Electron Microscope using SEM Model Quanta 250 FEG (Field Emission Gun).

\section{Examination of Iron Nano-composite Efficiency}

Batch adsorption studies were performed by mixing MNPs with 50 $\mathrm{ml}$ of the synthesized wastewater in a flask. For $\mathrm{pH}$ adjustment, standard 0.1 $\mathrm{M} \mathrm{HCl}$ and $0.1 \mathrm{M} \mathrm{NaOH}$ solutions were used. The solution mixture of MNPs was put with wastewater solution in sonicator for different times. After adsorption reached equilibrium, the adsorbent was conveniently separated via an external magnetic field and the solution was collected for metal concentration measurements. MNPs were washed thoroughly with deionized water to neutrality. The concentrations of metal ions were measured by a

Egyptian J. Desert Res., 68, No. 1, 15-36 (2018) 
plasma-atomic emission spectrometer (ICP-AMS, Optima 3000XL, PerkinElmer) in accordance with the Standard Method. In order to obtain reproducible experimental results, the adsorption experiments were carried out at least three times.

\section{Microbiological Experimentation \\ 4.1. Detection of microbial water pollution}

The total viable bacterial counts (TVBCs) at $22^{\circ} \mathrm{C}$ and $37^{\circ} \mathrm{C}$ were determined using the spread-plate method (APHA, 1995). The number of total and faecal coliforms was determined by the most probable number (MPN) method. The positive tubes were streaked on the Eosin Methylene Blue (EMB) agar plates. Microscopic examination was carried out to ensure gram-negative, non-spore forming rods.

4.2. Detection of MIC from two prepared nanoparticles $(150-500 \mu \mathrm{g} / \mathrm{ml})$ against different pathogenic gram-positive and gram-negative bacteria by using Inhibition Zone Test

The antimicrobial activity of different concentrations of prepared iron oxide nano-composites (150 to $500 \mu \mathrm{g} / \mathrm{ml}$ ) was investigated against four pathogenic bacterial strains representing gram-positive and gram-negative bacteria, namely, Escherichia coli, Klebsiella pneumonia, Bacillus subtilis and Staphylococcus aureus. The antimicrobial susceptibility test was done by Kirby-Bauer Disk Susceptibility Test and measuring Inhibition Zones (Bauer et al., 1966). MacConky agar, MacConky broth and nutrient agar were used as the growth media. All media were prepared according to the manufacturer's instructions. Cheesbrough method was followed to prepare filter paper disks of $6 \mathrm{~mm}$ diameter saturated with the two different nanoparticles concentrations (Cheesbrough, 2000). An inoculum of each bacterial isolate was prepared from the prepared bacterial suspension. In brief, sterile distilled water was used to emulsify $3-4$ colonies of the isolates and the turbidity was adjusted to $1.5 \times 10{ }_{8} \mathrm{CFU} / \mathrm{ml}$ (corresponding to 0.5 McFarland standards, which were prepared by the method of Koneman et al. (1997). A sterile cotton swab was immersed into the standardized bacterial suspension then inoculated on the agar plates evenly. The plates were dried for 2-5 min. Afterwards, all disks were placed on the plates and pressed gently to ensure adequate contact with agar. A distance of $12 \mathrm{~mm}$ at least was preserved from the edges of the plates to avoid overlapping of inhibition zones. An oxacillin disk (15 g) was used as a positive control. The plates were incubated at $37^{\circ} \mathrm{C}$ for $2-5$ days. Afterwards the plates were inspected and the diameter of the zone of inhibition was measured. 


\section{RESULTS AND DISCUSSION}

1. Characterization of the Iron Nano-composite with $\mathrm{TiO}_{2}$

\subsection{X-ray diffraction analysis (XRD)}

Fig. (1) shows the sharp peaks of $\mathrm{Fe}_{3} \mathrm{O}_{4}$ and $\mathrm{Fe}_{2} \mathrm{O}_{3}$ nanoparticles that have well crystallized structure. Fig. (2) shows peaks corresponding to the diffractions of $\mathrm{TiO}_{2}$ anatase, hematite, and magnetite spinal structure. The positions and relative intensities of the reflection peak of $\mathrm{Fe}_{3} \mathrm{O}_{4}$ and $\mathrm{Fe}_{2} \mathrm{O}_{3}$ MNPs agree with the XRD diffraction peaks of standard $\mathrm{Fe}_{2} \mathrm{O}_{3}$ samples (Mahdavi et al., 2007).

\begin{tabular}{ccc}
\hline Mineral name & Chemicalformula & Semi-quant (\%) \\
\hline Hematite & $\mathrm{Fe}_{2} \mathrm{O}_{3}$ & $\mathbf{6 0}$ \\
Maghemite & $\gamma-\mathrm{Fe}_{2} \mathrm{O}_{3}$ & $\mathbf{1 5}$ \\
Magnetite & $\mathrm{Fe}_{3} \mathrm{O}_{4}$ & $\mathbf{2 5}$ \\
\hline
\end{tabular}

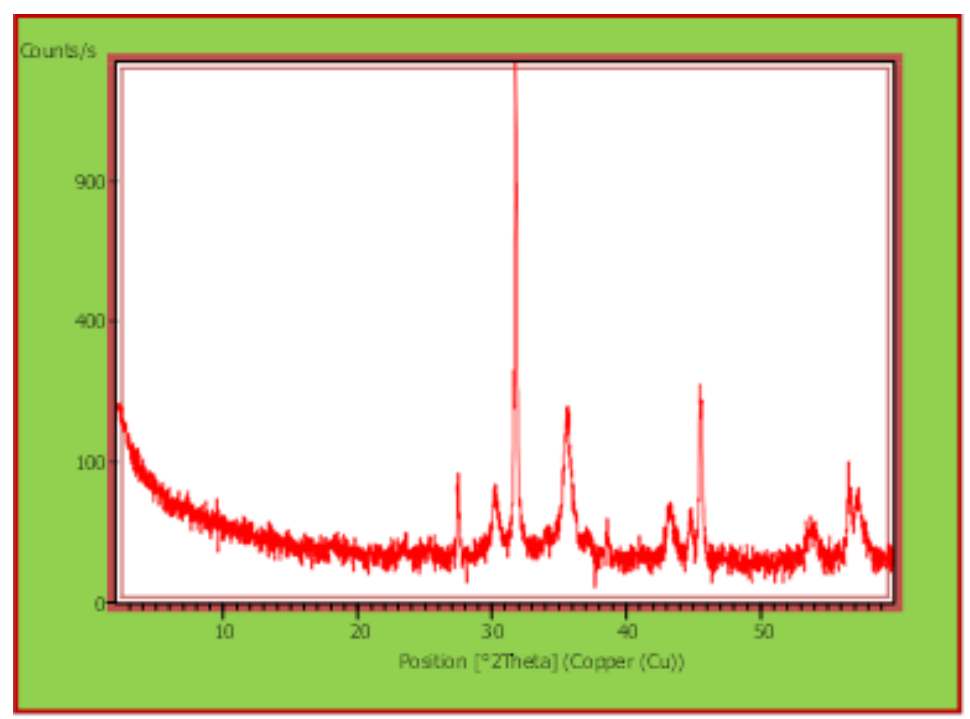

Fig. (1). X-ray diffraction of iron oxide nanoparticles.

\begin{tabular}{lcc}
\hline Mineral name & Chemical formula & Semi-quant (\%) \\
\hline Hematite & $\mathrm{Fe}_{2} \mathrm{O}_{3}$ & 45 \\
Titanium Oxide & $\mathrm{TiO}_{2}$ & 25 \\
Magnetite & $\mathrm{Fe}_{3} \mathrm{O}_{4}$ & 30 \\
\hline
\end{tabular}




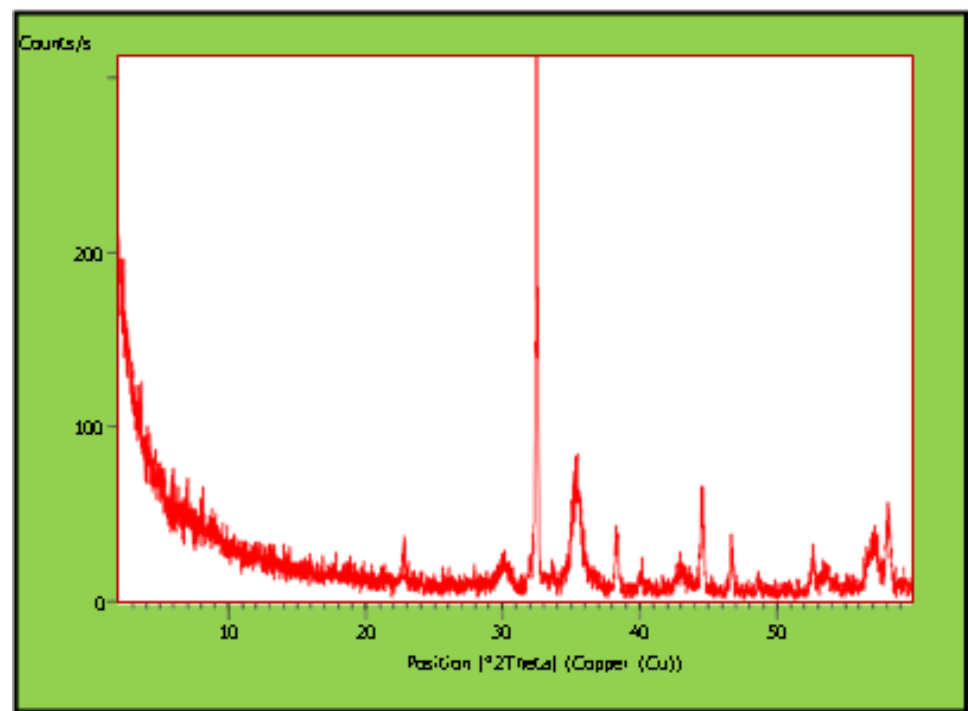

Fig. (2). X-ray diffraction of iron oxide nano-composite with $\mathrm{TiO}_{2}$.

\subsection{Scanning electron micrograph (SEM)}

SEM images in fig. (3) show surface area of iron oxide nanoparticles and nano-composite with $\mathrm{TiO}_{2}$, which consider as cubic and spherical shape of hematite nanoparticles merged with $\mathrm{TiO}_{2}$ in bending structure. The SEM photos show the effect of iron oxide to form nano-pellets with different shapes and the spherical pellet of iron oxide with nano-sized. However, fig. (4) illustrates the effect of $\mathrm{TiO}_{2}$ with iron oxide formed as a core pellet to form a new nano-composite. This nano-composite has new chemical and biochemical features and high surface area with small diameter.

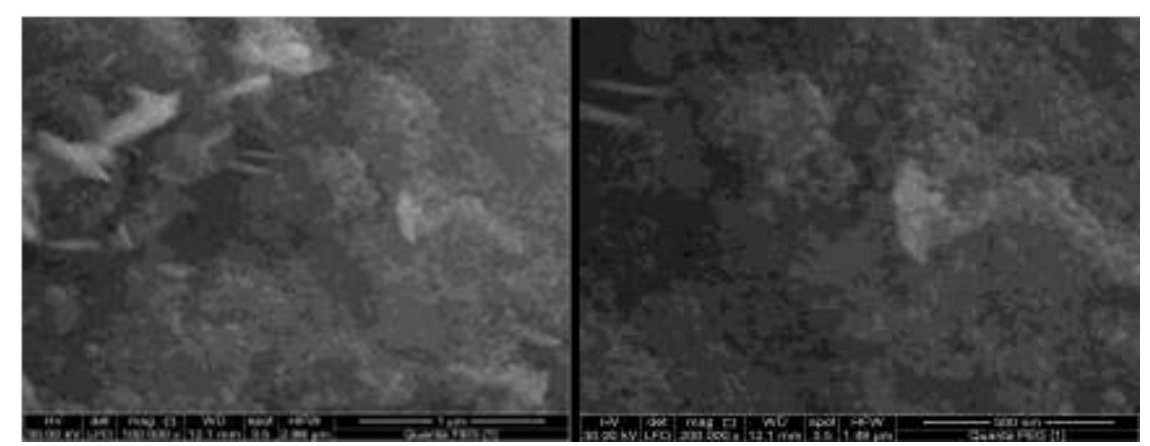

Fig. (3). Scanning electron microscope of iron oxide nanoparticles. 


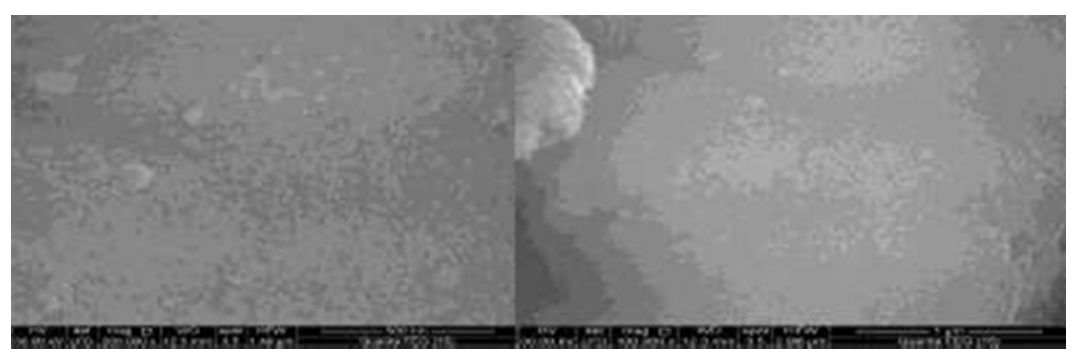

Fig. (4). Scanning electron microscope of iron nano-composite with $\mathrm{TiO}_{2}$.

\subsection{Particle size determination of iron oxide nano-composite}

The reduction percent (removal efficiency) depends mainly on the size of nanoparticles formed and the nature of core and coated materials to form nano-composite, which had large surface area had ability to remove heavy metals or any contaminant in polluted water. The mean particle size of iron oxide nano-composite with $\mathrm{TiO}_{2}$ showed that the iron oxide nanocomposite is nearly spherical and crystalline in shape. The nanoparticles intensity weighting was $92.60 \mathrm{~nm}$, volume weighting was $33.40 \mathrm{~nm}$ and number weighting was $15.50 \mathrm{~nm}$. The mean diameter of nano-composite material ranges around $47.16 \mathrm{~nm}$ (Fig. 5).

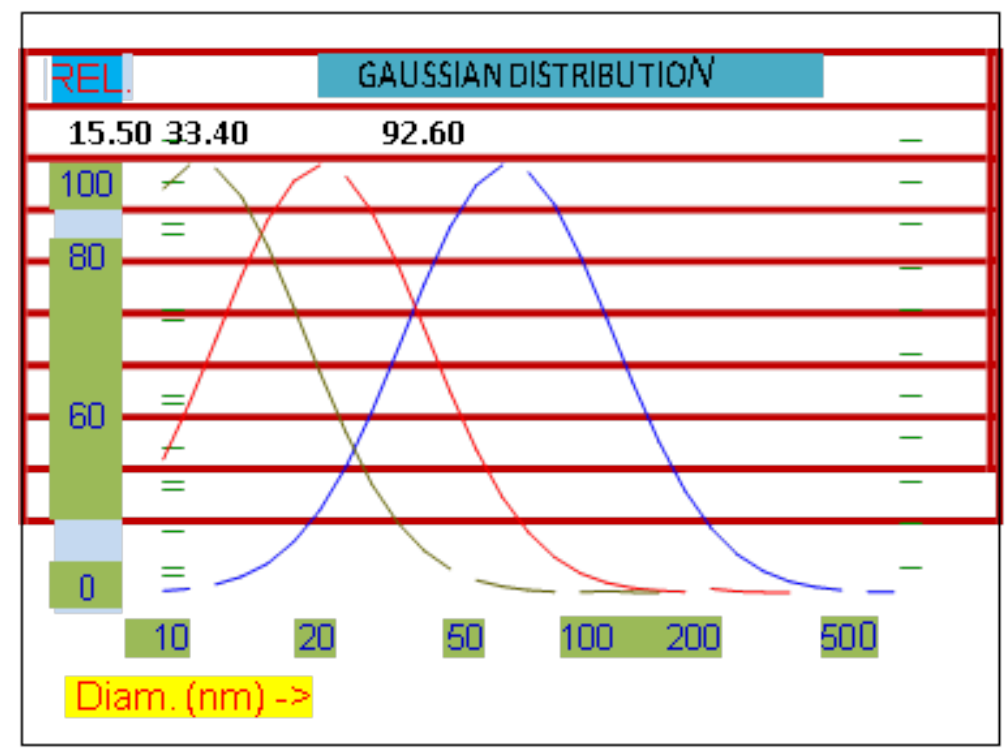

Fig. (5). Particle size analyzer of iron oxide nanoparticles.

\subsection{Vibrating sample magnetometer of iron oxide nano-composite}

The magnetization curves were measured at room temperature for iron oxide nanoparticles and iron oxide coated $\mathrm{TiO}_{2}$-anatase (Fig. 6). Magnetization showed no hysteresis, suggesting that produced magnetic 
particles are superparamagnetic (Pradhan et al., 2006). When the magnetic component size of the particles is smaller than critical size; these particles had super paramagnetism properties (Guo et al., 2010). The high saturation magnetization of pure $\mathrm{Fe}_{3} \mathrm{O}_{4}$ indicated the good crystal structure. Fig. (7) shows that the saturation magnetization values of $\mathrm{TiO}_{2}$ coated iron oxide was smaller than the value for the crude magnetite nanoparticles. Therefore, the saturation magnetization was reduced after coating of $\mathrm{TiO}_{2}$ onto the surface of iron oxide nanoparticles. The presence of diamagnetic shell on iron oxide nanoparticles causes this effect. The super paramagnetic behaviors showed in two figures indicating that magnetite and hematite nanoparticles were merged in the composite particles.

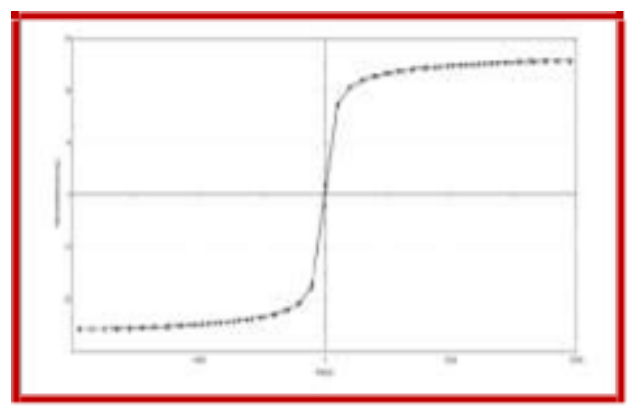

Fig. (6). Magnetization curve iron oxide nanoparticles.

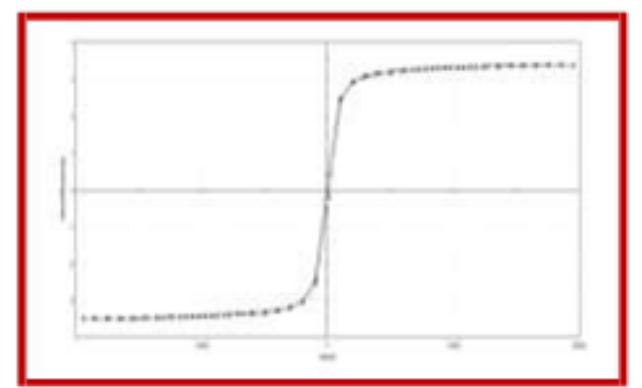

Fig. (7). Magnetization curve iron oxide nano-compositeTiO ${ }_{2}$

\section{Chemical Analysis of Wastewater Samples}

Represented data in table (1) show that, the mean value of $\mathrm{pH}$ of wastewater for collected samples was about 7.74 and this value is in normal range of standard level for good water. Also, average range of dissolved oxygen (DO) was $3.16 \mathrm{mg} / \mathrm{l}$. This value of DO considered as a moderate value for microbial contamination in water. The mean values of five collected samples of total nitrogen (TN) in wastewater were around 42.63 $\mathrm{mg} / \mathrm{l}$. This value had a slightly rise related to Egyptian standard specification of water quality. However, the total phosphorous (TP) of all collected samples was ranged in normal Egyptian standard specification for 
wastewater. The mean value of water salinity (Total Dissolved Substances) was $4598 \mathrm{mg} / \mathrm{l}$. The high salinity of water was due to the effect of leaching and dissolution of salty soil in this area.

Table (1). Chemical analysis of Al Tard-Bilraha Drain Ismailia before

\begin{tabular}{|c|c|c|c|c|c|}
\hline No. & pH & $\begin{array}{c}\mathrm{TP} \\
(\mathrm{mg} / \mathrm{l})\end{array}$ & $\begin{array}{c}\mathrm{TN} \\
(\mathrm{mg} / \mathrm{l})\end{array}$ & $\begin{array}{c}\text { DO } \\
(\mathrm{mg} / \mathrm{l})\end{array}$ & $\begin{array}{c}\text { TDS } \\
(\mathrm{mg} / \mathrm{l})\end{array}$ \\
\hline 1 & 7.54 & 1.25 & 52.01 & 2.50 & 4200 \\
\hline 2 & 8.01 & 1.82 & 41.12 & 3.47 & 4258 \\
\hline 3 & 7.63 & 1.42 & 40.10 & 2.91 & 4500 \\
\hline 4 & 7.28 & 1.89 & 42.78 & 3.50 & 4920 \\
\hline 5 & 8.25 & 2.01 & 37.18 & 3.46 & 5112 \\
\hline
\end{tabular}

TDS: total dissolved salts, DO: dissolved oxygen, TN: total nitrogen, TP: total phosphorus

Table (2) illustrates that the mean value of total suspended solids was $25.80 \mathrm{mg} / \mathrm{l}$. The chemical oxygen demand (COD) was considered as organic pollutants with some inorganic pollutants. The mean value of chemical oxygen demand of polluted water was $26.99 \mathrm{mg} / \mathrm{l}$. The mean value of biochemical oxygen demand (BOD) was $16.24 \mathrm{mg} / \mathrm{l}$. Extensive observation of the COD and BOD levels on the same wastewater has shown that the COD to BOD ratio of a particular wastewater will remain constant over time.

Table (2). Chemical analysis of Al Tard-Bilraha Drain Ismailia before treatment.

\begin{tabular}{ccccc}
\hline No. & $\begin{array}{c}\text { TSS } \\
(\mathbf{m g} / \mathbf{l})\end{array}$ & $\begin{array}{c}\text { COD } \\
(\mathbf{m g} / \mathbf{l})\end{array}$ & $\begin{array}{c}\text { BOD } \\
\text { (mg/l) }\end{array}$ & $\begin{array}{c}\text { COD/BOD } \\
\text { ratio }\end{array}$ \\
\hline 1 & 22 & 25.22 & 15.78 & 37.43 \\
2 & 24 & 27.74 & 19.76 & 28.76 \\
3 & 19 & 31.54 & 16.41 & 47.97 \\
4 & 29 & 29.11 & 17.28 & 40.63 \\
5 & 35 & 21.36 & 12.01 & 43.77 \\
\hline
\end{tabular}

TSS: total suspended solids, COD: chemical oxygen demand, BOD: biochemical oxygen demand

The heavy metals concentrations (Table 3) in collected polluted water were in standard level range as global standards specification and Egyptian standards, except iron and aluminum ions. Water treatment occurred to remove iron and aluminum by prepared iron oxide nanoparticles and nano-composite of iron oxide coated by $\mathrm{TiO}_{2}$.

Egyptian J. Desert Res., 68, No. 1, 15-36 (2018) 
Table (3). Heavy (toxic) metals of Al Tard-Bilraha Drain Ismailia before treatment.

\begin{tabular}{ccccccccccccc}
\hline & \multicolumn{10}{c}{ Heavy metals conc. $(\mathbf{m g} / \mathbf{l})$} \\
\cline { 2 - 13 } & $\mathbf{A l}$ & Cd & Co & Cr & Cu & Fe & Mn & Mo & Ni & Pb & V & Zn \\
\hline 1 & 1.540 & ND & ND & 0.098 & 0.020 & 1.345 & 0.254 & 0.025 & 0.011 & 0.098 & 0.741 & 0.010 \\
2 & 4.295 & ND & ND & 0.168 & ND & 1.421 & 0.120 & 0.011 & 0.012 & 0.045 & 0.802 & ND \\
3 & 0.987 & ND & ND & 0.01 & ND & 0.752 & 0.048 & 0.014 & ND & 0.027 & 0.01 & 0.008 \\
4 & 1.211 & ND & ND & 0.101 & ND & 2.321 & 0.201 & 0.014 & 0.008 & 0.035 & 0.020 & 0.010 \\
5 & 1.020 & ND & ND & 0.145 & ND & 4.158 & 0.197 & 0.045 & 0.017 & 0.078 & 0.025 & ND \\
\hline
\end{tabular}

\subsection{Effect of iron oxide nano-composite after treatment}

Table (4) shows the effect of iron oxide nanoparticles and iron oxide with $\mathrm{TiO}_{2}$ nano-composite in reducing chemical oxygen demand concentrations. The mean value of reduction percent of chemical oxygen demand was $33.29 \%$. Nano-composite had the ability to reduce the organic matters pollutants. The mean value of reduction percent of BOD was $76.61 \%$. Biochemical oxygen demand could be affected by the iron nano- composite. This was indication the high removal efficiency of nano- composite asantibactericidal.

Table (4). Chemical Analysis of Al Tard-Bilraha Drain Ismailia after treatment.

\begin{tabular}{ccccccc}
\hline No. & $\begin{array}{c}\text { COD } \\
(\mathbf{m g} / \mathbf{l})\end{array}$ & $\begin{array}{c}\text { COD } \\
\text { (mg/l) }\end{array}$ & $\begin{array}{c}\text { Reduction } \\
\mathbf{( \% )}\end{array}$ & $\begin{array}{c}\text { BOD }_{\mathbf{5}} \\
\mathbf{( m g / l )} \\
\text { before }\end{array}$ & $\begin{array}{c}\text { BOD } 5 \\
(\mathbf{m g} / \mathbf{l})\end{array}$ & $\begin{array}{c}\text { Reduction } \\
\mathbf{a f t e r}\end{array}$ \\
\hline 1 & 25.22 & 17.78 & 29.50 & 15.78 & 2.45 & 84.47 \\
2 & 27.74 & 16.45 & 40.69 & 19.76 & 4.27 & 78.39 \\
3 & 31.54 & 20.01 & 36.55 & 16.41 & 3.97 & 75.81 \\
4 & 29.11 & 19.62 & 32.60 & 17.28 & 4.64 & 73.15 \\
5 & 21.36 & 15.57 & 27.10 & 12.01 & 3.45 & 71.27 \\
\hline
\end{tabular}

TSS: total suspended solids, COD: chemical oxygen demand, BOD: biochemical oxygen demand

Optimal condition: $0.15 \mathrm{mg} / \mathrm{ml}$ (nanoparticles conc.) at $25^{\circ} \mathrm{C}$ and $\mathrm{PH} 7$ for $15 \mathrm{~min}$ (El-Sayed and Abdulhady, 2015) 


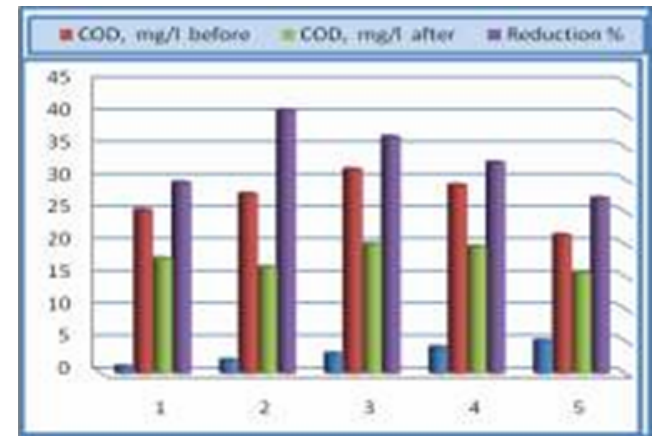

Fig. (8). Relation between COD removal and reduction percent.

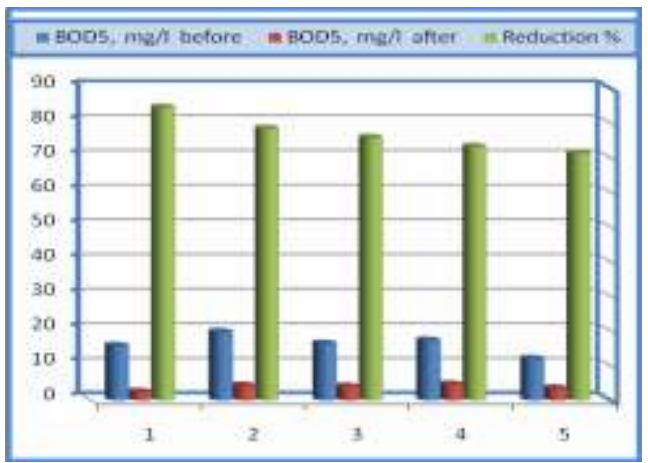

Fig. (9). Relation between BOD removal and reduction percent.

\subsection{Removal of total nitrogen by iron nano-composite}

Reduction percent ranged from $68.22 \%$ (sample 3 ) to $78.35 \%$ (sample 1) (Table 5 and Fig. 10). High removal efficiency of iron nano-composite on reducing nitrogen compounds in wastewater samples was shown. The nitrogen atoms nitro-compound was adsorbed on iron oxide nanoparticles cross chemical electro-static binding with oxygen atom of hydroxyl group.

Table (5). Chemical analysis of Al Tard-Bilraha Drain after treatment.

\begin{tabular}{cccc}
\hline No. & $\begin{array}{c}\text { TN (mg/l) } \\
\text { before }\end{array}$ & $\begin{array}{c}\text { TN (mg/l) } \\
\text { after }\end{array}$ & $\begin{array}{c}\text { Reduction } \\
\mathbf{( \% )}\end{array}$ \\
\hline 1 & 52.01 & 11.26 & 78.35 \\
2 & 41.12 & 10.98 & 73.29 \\
3 & 40.10 & 12.74 & 68.22 \\
4 & 42.78 & 13.09 & 69.40 \\
5 & 37.18 & 09.14 & 75.41 \\
\hline
\end{tabular}

Optimal condition: $0.15 \mathrm{mg} / \mathrm{ml}$ (nanoparticles conc.) at $25^{\circ} \mathrm{C}$ and $\mathrm{PH} 7$ for $15 \mathrm{~min}$ (El-Sayed and Abdulhady, 2015). 


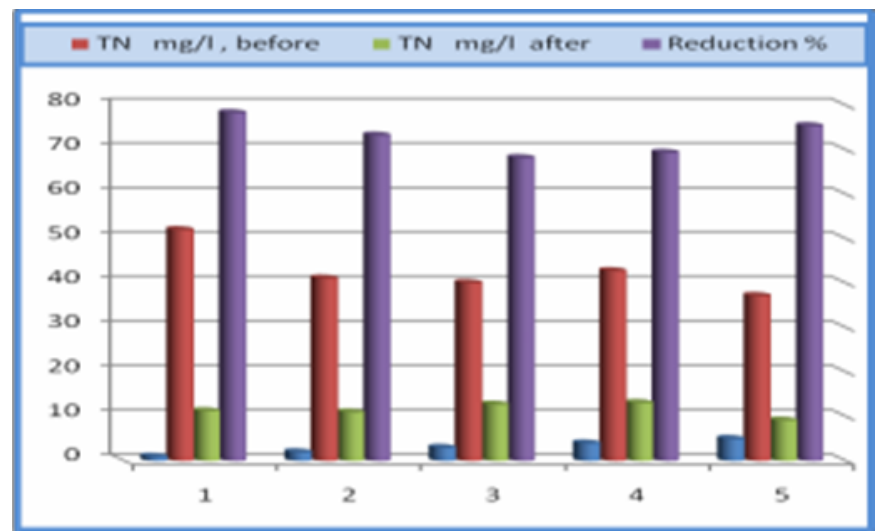

Fig. (10). Relation between TN removal and reduction percent.

\subsection{Removal of iron and aluminum metals by iron nano-composite}

Table (6) and Fig. (11 and 12) discuss the reduction percent of removal iron and manganese ions from wastewater. Data explained the high value of iron reduction percent from 83.17 to $95.66 \%$ and for manganese reduction percent from $74.26 \%$ (in sample 1) to $90.90 \%$ (in sample 4 ).

Table (6). Heavy (toxic) metals of Al Tard-Bilraha Drain Ismailia after treatment.

\begin{tabular}{ccccccc}
\hline No. & $\begin{array}{c}\text { Iron } \\
(\mathbf{m g} / \mathbf{l}) \\
\text { before }\end{array}$ & $\begin{array}{c}\text { Iron } \\
\mathbf{( m g / \mathbf { l } )} \\
\mathbf{a f t e r}\end{array}$ & $\begin{array}{c}\text { Reduction } \\
\mathbf{( \% )}\end{array}$ & $\begin{array}{c}\text { Aluminum } \\
\mathbf{( m g / \mathbf { l } )} \\
\text { before }\end{array}$ & $\begin{array}{c}\text { Aluminum } \\
\mathbf{( m g / \mathbf { l } )} \\
\mathbf{a f t e r}\end{array}$ & $\begin{array}{c}\text { Reduction } \\
\mathbf{( \% )}\end{array}$ \\
\hline 1 & 1.345 & 0.15 & 88.84 & 1.540 & 0.425 & 72.40 \\
2 & 1.421 & 0.32 & 77.48 & 4.295 & 1.254 & 70.80 \\
3 & 0.752 & 0.28 & 62.76 & 0.987 & 0.356 & 63.93 \\
4 & 2.321 & 0.41 & 82.33 & 1.211 & 0.478 & 60.52 \\
5 & 4.158 & 0.39 & 90.62 & 1.020 & 0.347 & 65.98 \\
6 & 1.345 & 0.27 & 79.92 & 1.540 & 0.490 & 68.18 \\
\hline
\end{tabular}

Optimal condition: $0.15 \mathrm{mg} / \mathrm{ml}$ (nanoparticles conc.) at $25^{\circ} \mathrm{C}$ and $\mathrm{PH} 7$ for $15 \mathrm{~min}$ (El-Sayed and Abdulhady, 2015). 


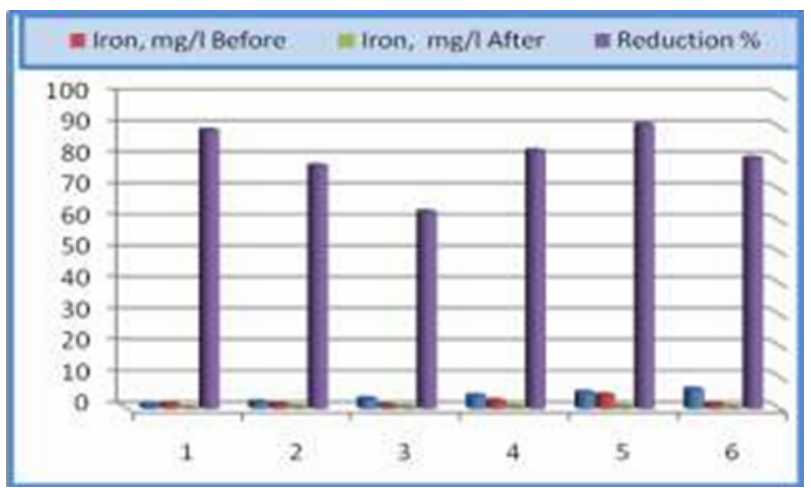

Fig (11). Relation between iron removal and reduction percent.

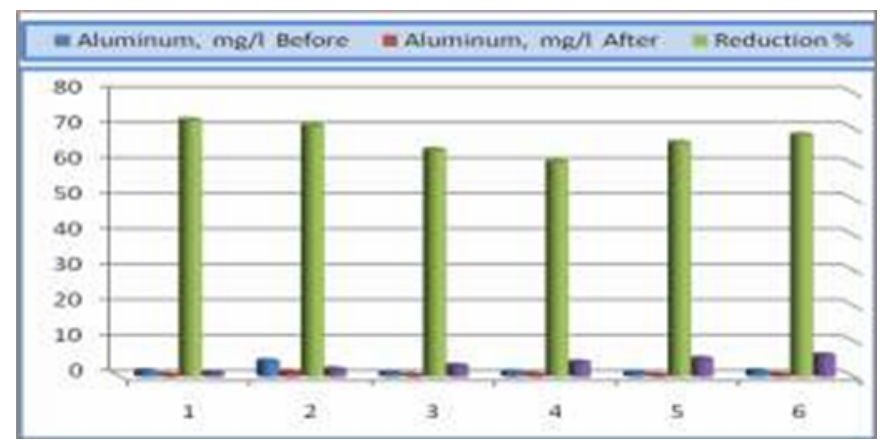

Fig (12). Relation between aluminum removal and reduction percent.

\section{Effect of Iron Nano-Composite on Bacteriological Contamination}

The total number of bacteria in most samples recorded $300 \mathrm{cfu} / \mathrm{ml}$. The bacteriological analyses involved total viable bacterial counts (TVBCs) and total coliforms. The results of the total number of bacteria are shown in Table (7). The most probable number of faecal indicators total coliforms (TC) is also shown in table (7). MPN of TC $1100 / 100 \mathrm{ml}$ recorded the upper limits for microbial pollution. The highest bacterial indicators were recorded at Al Tard-Bilraha Drain Ismailia. This might be explained by the effect of domestic and agricultural wastes discharge from the urbanized surrounding area (Bateganya et al., 2015). 
Table (7). Microbial analysis of Al Tard-Bilraha Drain Ismailia before treatment.

\begin{tabular}{ccccccc}
\hline No. & $\begin{array}{c}\text { Total fecal coil } \\
\text { form count/ } \\
\text { CFU/100 ml }\end{array}$ & $\begin{array}{c}\text { Total } \\
\text { microbial } \\
\text { count } \\
\text { CFU/ml }\end{array}$ & E. coli & K. pneumonia & B. subtilis & S.aureus \\
\hline 1 & 1100 & $>30$ & $+\mathrm{ve}$ & $+\mathrm{ve}$ & $-\mathrm{ve}$ & $-\mathrm{ve}$ \\
2 & 1100 & 0 & & & & \\
3 & 1100 & 300 & $+\mathrm{ve}$ & $-\mathrm{ve}$ & $+\mathrm{ve}$ & $-\mathrm{ve}$ \\
4 & 1100 & 280 & $+\mathrm{ve}$ & $+\mathrm{ve}$ & $+\mathrm{ve}$ & $+\mathrm{ve}$ \\
5 & 1100 & 260 & $+\mathrm{ve}$ & $-\mathrm{ve}$ & $-\mathrm{ve}$ & $+\mathrm{ve}$ \\
\hline
\end{tabular}

3.1. Detection on minimum inhibitory concentration (MIC) for iron oxide nanoparticles

Several primary tests were tested the efficiency of iron oxide nanoparticles and iron oxide coated by $\mathrm{TiO}_{2}$ nano-composite. The experiments discussed the effect of different concentrations of iron oxide nano-composite against gram-positive and gram-negative pathogenic bacteria (Table 8 and 9). The iron oxide nano-composite concentrations were in the range of 150 to $500 \mu \mathrm{g} / \mathrm{ml}$. This article had discussed optimization condition of definite quantity of iron oxide nano-composite required to get on highly efficient antibacterial action (Koneman et al., 1997; Cheesbrough, 2000 and Mahdavi et al., 2013).

Table (8). Antimicrobial activity of different concentration of iron oxide nanoparticles.

\begin{tabular}{ccccc}
\hline $\begin{array}{c}\text { Nanoparticles } \\
\text { conc. } \\
(\boldsymbol{\mu g} / \mathbf{m l})\end{array}$ & E. coli & K. pneumonia & B. subtilis & S. aureus \\
\hline 500 & 2.1 & 2.5 & 2.0 & 2.7 \\
450 & 1.8 & 2.4 & 1.5 & 1.6 \\
400 & 1.7 & 2.0 & 1.4 & 1.4 \\
350 & 1.5 & 1.9 & 0.9 & 0.9 \\
300 & 1.4 & 1.7 & 0.7 & 0.5 \\
250 & 1.3 & 1.3 & 0.4 & 0.2 \\
200 & 1.0 & 1.1 & 0.3 & 0.1 \\
175 & 0.8 & 0.7 & 0.2 & 0.0 \\
150 & 0.7 & 0.5 & 0.0 & 0.0 \\
\hline
\end{tabular}


Table (9). Antimicrobial activity of different concentration of iron oxide coated by $\mathrm{TiO}_{2}$ nano-composite.

\begin{tabular}{ccccc}
\hline $\begin{array}{c}\text { Nanoparticles } \\
\text { conc. } \\
(\boldsymbol{\mu g} / \mathbf{m l})\end{array}$ & E. coli & K. pneumonia & B. subtilis & S. aureus \\
\hline 500 & 4.9 & 2.5 & 3.2 & \\
450 & 4.3 & 2.3 & 2.7 & 2.5 \\
400 & 3.8 & 1.7 & 2.4 & 2.4 \\
350 & 3.4 & 1.5 & 2.1 & 2.2 \\
300 & 3.2 & 1.4 & 1.4 & 2.0 \\
250 & 2.3 & 1.2 & 1.2 & 1.9 \\
200 & 1.4 & 1.0 & 1.1 & 1.8 \\
175 & 1.1 & 0.7 & 0.9 & 1.7 \\
150 & 0.0 & 0.6 & 0.8 & 1.6 \\
\hline
\end{tabular}

3.2. Effect of prepared nanoparticles $(150 \mu \mathrm{g} / \mathrm{ml})$ elements on microbial water pollution of Al Tard-Bilraha Drain Ismailia at different time intervals

The best reaction time needed to remove microbial pollution from Al Tard-Bilraha Drain Ismailia, using iron oxide nano-composite as a removal anti-bacterial in water samples at concentration of $150 \mu \mathrm{g} / \mathrm{ml}$, then determination of microbial pollution were estimated after 5,10,15, 20, 25 and $30 \mathrm{~min}$. Total coli-forms counts decreased with increasing time till 30 min, which recorded $100 \%$ reduction (Table $10 \& 11$ and Fig. $13 \& 14$ ).

Table (10). Effect of prepared iron oxide nanoparticles $(150 \mu \mathrm{g} / \mathrm{ml})$ element on microbial water pollution of Al Tard-Bilraha Drain Ismailia at different time interval.

\begin{tabular}{cccc}
\hline $\begin{array}{c}\text { Time } \\
(\mathbf{m i n})\end{array}$ & $\begin{array}{c}\text { Total Coli form } \\
\text { before treatments }\end{array}$ & $\begin{array}{c}\text { Total Coli form } \\
\text { after treatments }\end{array}$ & $\begin{array}{c}\text { Reduction } \\
\mathbf{( \% )}\end{array}$ \\
\hline 5 & 1100 & 420 & 61.80 \\
10 & 1100 & 250 & 77.27 \\
15 & 1100 & 150 & 86.36 \\
20 & 1100 & 65 & 94.08 \\
25 & 1100 & 9 & 99.18 \\
30 & 1100 & 0 & 100.00 \\
\hline
\end{tabular}

Egyptian J. Desert Res., 68, No. 1, 15-36 (2018) 


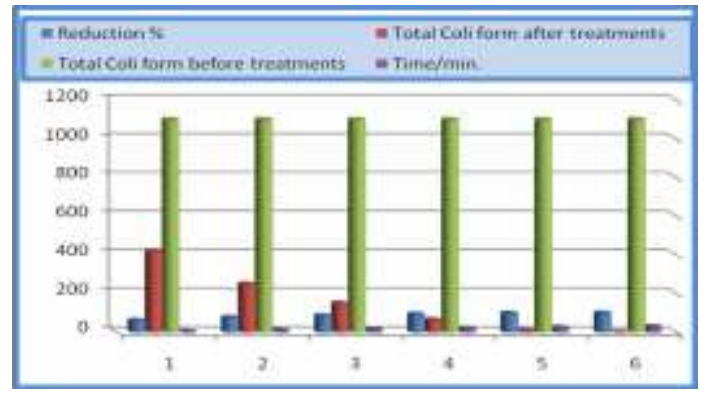

Fig. (13). Relation between inhibition time and reduction percent of prepared iron oxide nanoparticles.

Table (11). Effect of iron oxide coated by $\mathrm{TiO}_{2}$ nano-composite $(150 \mu \mathrm{g} / \mathrm{ml})$ element on microbial water pollution of Al Tard-Bilraha Drain Ismailia at different time interval.

\begin{tabular}{cccc}
\hline $\begin{array}{c}\text { Time } \\
(\mathbf{m i n})\end{array}$ & $\begin{array}{c}\text { Total Coli form } \\
\text { before treatments }\end{array}$ & $\begin{array}{c}\text { Total Coli form } \\
\text { after treatments }\end{array}$ & $\begin{array}{c}\text { Reduction } \\
\mathbf{( \% )}\end{array}$ \\
\hline 5 & 1100 & 220 & 80.00 \\
10 & 1100 & 140 & 87.30 \\
15 & 1100 & 95 & 91.30 \\
20 & 1100 & 35 & 96.81 \\
25 & 1100 & 8 & 99.30 \\
30 & 1100 & 0 & 100.00 \\
\hline
\end{tabular}

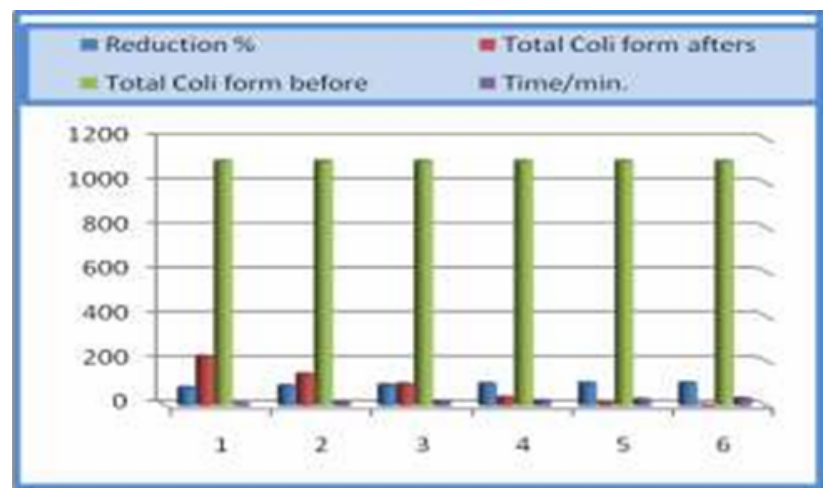

Fig. (14). Relation between inhibition time and reduction percent of iron oxide coated by $\mathrm{TiO}_{2}$ nano-composite.

\section{CONCLUSION}

The main research target of this article was heavy (toxic) metals removal and investigated the antibacterial activities of iron oxide nanoparticles and iron oxide nano-composite with $\mathrm{TiO}_{2}$. Screening of 
different microbes in polluted water to identify the microbial species, and mixed with definite concentration of iron oxide nanoparticles and iron oxide nano-composite with $\mathrm{TiO}_{2}$ individual, at different reaction time, to get on the best reduction percent at lowest time period. Reduction percent was affected by magnetic properties of iron oxide nanoparticles and iron oxide nanocomposite with $\mathrm{TiO}_{2}$. The highest removal efficiency (reduction percent) of iron and aluminum from wastewater by prepared iron oxide nanoparticles and iron oxide nano-composite with $\mathrm{TiO}_{2}$ were 90.62 and $72.40 \%$, respectively. The anti- bacterial activity showed the high reduction percent after $30 \mathrm{~min}$ by $150 \mu \mathrm{g} / \mathrm{ml}$ of prepared iron nanoparticles. The highest value of reduction percent was achieved for removal iron and aluminum ions from polluted water, and also moderate effect on decreasing chemical and biochemical oxygen demand concentration with decreasing percent of total nitrogen concentration.

\section{REFERENCES}

APHA (American Public Health Association) (1995).In "Standard Methods for the Examination for Water and Wastewater". $19^{\text {th }}$ edition.Byrd Prepess Springfield, Washington, US.

Asharani, P.V., Y.L. Wu, Z. Gong and S. Valiyaveettil (2008). Toxicity of silver nanoparticles in zebrafish models. Nanotechnology, 19: 255102-255110.

Bauer, A.W., W.M. Kirby, J.C. Sherris and M.Turck (1966). Antibiotic susceptibility testing by a standardized single disk method. Am. J. Clin. Pathol., 45: 493-496.

Cheesbrough, M. (2000). In "District Laboratory Practice in Tropical Countries". Part II. Cambridge University Press, p. 1933-1934.

Chorianopoulos, N.G., D.S. Tsoukleris, E.Z. Panagou, P. Falaras and G.-J.E. Nychas (2011). Use of titanium dioxide $\left(\mathrm{TiO}_{2}\right)$ photo catalysts as alternative means for Listeria mono-cyto-genes biofilm disinfection in food processing. Food Microbiology, 28: 164-170.

El Saesser, A. and C.V. Howard (2010). Toxicology of nanoparticles. Advanced Drug Delivery Reviews, 64 (2): 129-137.

El-Sayed, M. and Y.A.M. Abdulhady (2015). Heavy metals removal by using magnetic iron oxide/ $/ \mathrm{TiO}_{2}$ nanocomposite for wastewater treatment in $10^{\text {th }}$ of Ramadan city, Egypt. Egyptian J. Desert Res., 65 (1): 81-99.

Feynman, R. (1991). There's plenty of room at the bottom. Science, 254: 1300-1301.

Fujishima, A. and K. Honda (1972). Electrochemical photocatalysis of water at semiconductor electrode. Nature, 238: 27-38.

Fujishima, A., K. Hashimoto and T. Watanabe (1992). In "TiO 2 PhotoCatalysis: Fundamentals and Applications". BKC Inc., Japan.

Egyptian J. Desert Res., 68, No. 1, 15-36 (2018) 
Gajjar, P., B. Pettee, D.W. Britt, W. Huang, W.P. Johnson and J. Anderson (2009). Antimicrobial activities of commercial nanoparticles against an environmental soil microbe, Pseudomonas putida KT2440. Journal of Biological Engineering, 3: 9-22.

Guo, L., G. Liu, R.Y. Hong and H.Z. Li (2010). Preparation and characterization of chitosan poly (acrylic acid) magnetic microspheres. Marine Drugs, 8: 2212-2222.

Gutierrez, F.M., P.L. Olive, A. Banuelos, E. Orrantia, N. Nino, E.M. Sanchez, F. Ruiz, H. Bach and Y.A. Gay (2010). Synthesis, characterization, and evaluation of antimicrobial and cytotoxic effect of silver and titanium nanoparticles. Nanomedicine, 6: 681688.

Hong, R.Y., S.Z. Zhang, Y.P. Han, H.Z. Li, J. Ding and Y. Zheng (2006). Preparation, characterization and application of bilayer surfactantstabilized ferrofluids. Powder Technology, 170: 1-11.

Indira, T.K. and P.K. Lakshmi (2010). Magnetic nanoparticles - A review.

Int. J. Pharm. Sci. Nanotechnol., 3: 1035-1042.

Ireland, J.C., P. Klostermann, E.W. Rice, and R.M. Clark (1993). Inactivation of Escherichia coli by titanium dioxide photocatalytic oxidation. Appl. Environ. Microbial., 59: 1668-1670.

Kievit, F.M. and M.Q. Zhang (2011). Surface engineering of iron oxide nanoparticles for targeted cancer therapy. Accounts of Chemical Research, 44 (10): 853-862.

Kolar, M., K. Urbanek and T. Latal (2001). Antibiotic selective pressure and development of bacterial resistance. Int. J. Ant. Microbe Ag., 17: 357-363.

Koneman, E.W., S.D. Allen, W.M. Janda, P.C. Schreckenberger and W.C. Winn (1997). In "Diagnostic Microbiology".5th edition, Philadelphia, Lippincott, p. 803-841.

Laurent, S., D. Forge, M. Port, A. Roch, C. Robic, L.E. Vander and R.N. Muller (2008). Magnetic iron oxide nanoparticles: synthesis, stabilization, vectorization, physicochemical characterizations, and biological applications. Chemical Reviews, 108 (6): 2064-2110.

Laurent, S., S. Dutz, U.O. Häfeli and M. Mahmoudi (2011). Magnetic fluid hyperthermia: focus on superparamagnetic iron oxide nanoparticles. Advances in Colloid and Interface Science, 166 (12): 8-23.

Mahdavi, M., F. Namvar, M.B. Ahmad and R. Mohamad (2013). Green biosynthesis and characterization of magnetic iron oxide $\left(\mathrm{Fe}_{3} \mathrm{O}_{4}\right)$ nanoparticles using seaweed (Sargassum muticum). Molecules, 18: 5954-5964.

Mahdavi, M., F. Namvar, M.B. Ahmad and R. Mohamad (2007). Green biosynthesis and characterization of magnetic iron oxide $\left(\mathrm{Fe}_{3} \mathrm{O}_{4}\right)$ 
nanoparticles using seaweed (Sargassum muticum) aqueous extract. Moecules, 18: 5954-596.

Mahmoudi, M., S. Sant, B. Wang, S. Laurent and T. Sen (2011). Superparamagnetic iron oxide nanoparticles (SPIONs): development, surface modification and applications in chemotherapy. Advanced Drug Delivery Reviews, 63 (1-2): 24-46.

Matsunaga, T., R. Tomada, T. Nakajima and H. Wake (1998). Photochemical sterilization of microbial cells by semiconductor powders.FEMS Microbiol. Lett., 29: 211-214.

Matsunga, T., R. Tomoda, T. Nakajima, N. Nakamura and T. Kmine (2005).Continuous-sterilization system that uses photosemiconductor powders. Appl. Environ. Microbiol., 1988. 54: 1330-1333.

Montferrand, C.de., L. Hu, I. Milosevic, R. Vincent, B. Dominique, M. Laurence, B. Arnaude and L. Yoann (2013). Iron oxide nanoparticles with sizes, shapes and compositions resulting in different magnetization signatures as potential labels for multiparametric detection. Acta Biomaterialia, 9 (4): 6150-6157.

Bateganya, N.L., D. Nakalanzi, M. Babu and T. Hein (2015). Bufferingmunicipal wastewater pollution using urban wetlands in sub-Saharan Africa: a case of Masaka municipality, Uganda Environmental Technology, 36: 17.

Pham, H.N., T. McDowell and E. Wikins (1995). Photo-catalyticallymediated disinfection of water using $\mathrm{TiO}_{2}$ as a catalyst and sporeforming Bacillus pumilusasa model. J. Environ. Sci. Health A., 30: 627-636.

Pradhan, P., J. Giri, G. Samanta, H.D. Sarma, K.P. Mishra, J. Bellare, R. Banerjee and D. Bahadur (2006). Comparative evaluation of heating ability and biocompatibility of different ferrite-based magnetic fluids for hyperthermia application. J. Biomed. Mater. Res., 81B: 12-22.

Schrand, A.M., M.F. Rahman, S.M. Hussain, J.J. Schlager, D.A. Smith and A.F. Syed (2010). Metal-based nanoparticles and their toxicity assessment. Nanomed. Nanobiotechnol., 2: 544-568.

Shaw, S.Y., E.C. Westly, M.J. Pittet, A. Subramanian, S.L. Schreiber and R. Weissleder (2008). Perturbational profiling of nanomaterial biologic activity. Proc. Natl. Acad. Sci., 105: 7387-7392.

Sugimoto, T. and K. Sakata (1992). Preparation of monodisperse pseudocubic $\alpha-\mathrm{Fe}_{2} \mathrm{O}_{3}$ particles from condensed ferric hydroxide gel. J. Colloid Interf. Sci., 152: 587-590.

Sugimoto, T., K. Sakata and A. Muramatsu (1993). Formation mechanism of monodisperse pseudocubic $\alpha-\mathrm{Fe}_{2} \mathrm{O}_{3}$ particles from condensed ferric hydroxide gel. J. Colloid Interf. Sci., 159 (2): 372-382.

Wei, C., W.Y. Lin, Z. Zainal, N.E. Williams, K. Zhu, A.P. Kruzic, R.L.

Egyptian J. Desert Res., 68, No. 1, 15-36 (2018) 
Smith and K. Rajeshwar (1994). Bactericidal activity of $\mathrm{TiO}_{2}$ photo catalyst in aqueous media: toward a solar-assisted water disinfection system. Environ. Sci. Technol., 28: 934-938.

Woo, K., J. Hong, S. Choi, H. Lee, J. Ahn, C. Sung and S.W. Lee (2004). Easy synthesis and magnetic properties of iron oxide nanoparticles. Chemistry of Materials, 16 (14): 2814-2818.

Xiao, L., J. Li, D.F. Brougham, K.F. Eoin, F. Neus, B. Alexey, S. Annette, M. Natascha, K. Fabian, V. Martin, F. Bengt and M. Sanjay (2011). Water-soluble superparamagnetic magnetite nanoparticles with biocompatible coating for enhanced magnetic resonance imaging. ACS Nano., 5 (8): 6315-6324. 


$$
\begin{aligned}
& \text { إزالة بعض العناصر الثقيلة والملوثات البكتيرية بإستخدام متر اكب الحديا }
\end{aligned}
$$

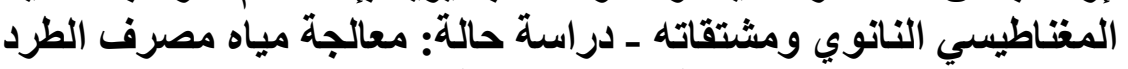

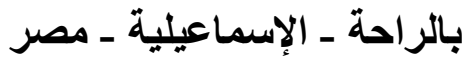

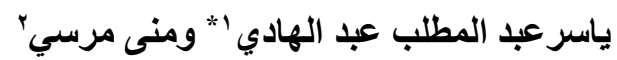

$$
\begin{aligned}
& \text { 'وحدة المعالجة وتحلية المياه، قسم الهيدروجيو كيمئياء }
\end{aligned}
$$

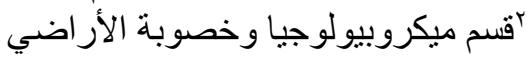

يهدف البحث إلى الإستفادة من تكنولوجيا تحضيربعض المواد النانوية من أيونات أكاسبد

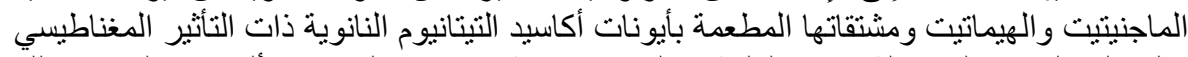

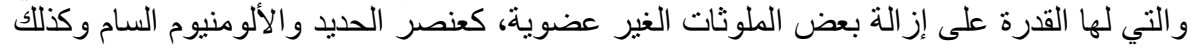

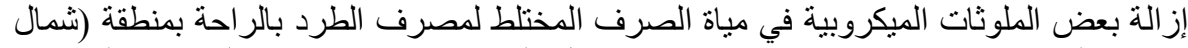

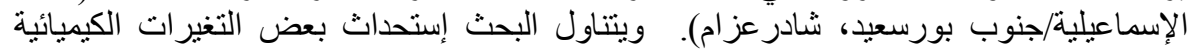

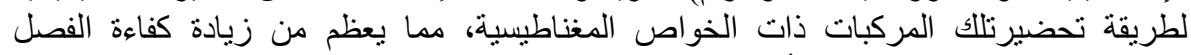

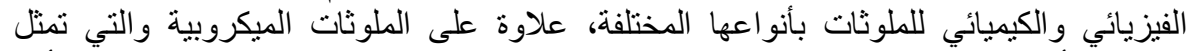

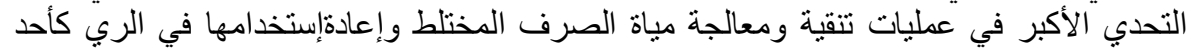

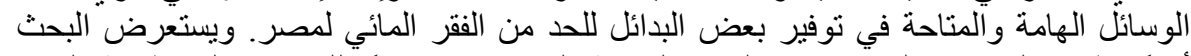

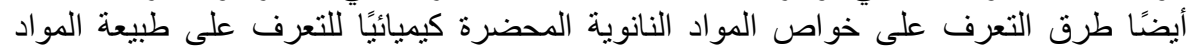

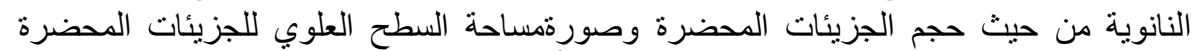

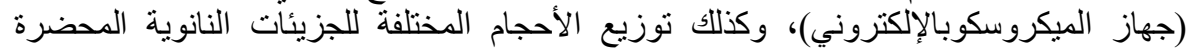

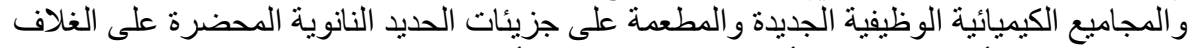

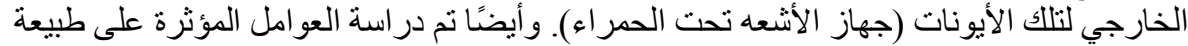

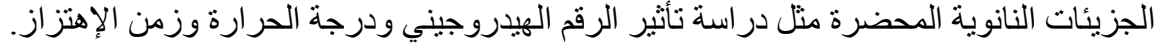

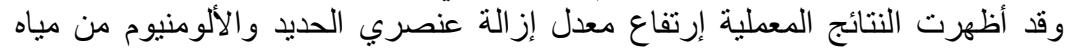

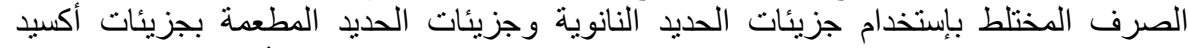

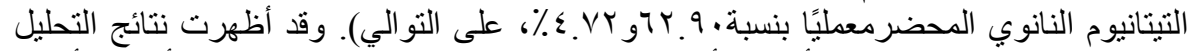

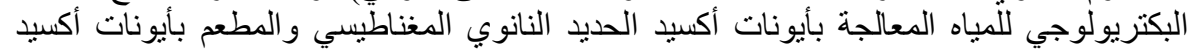

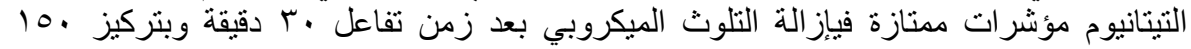

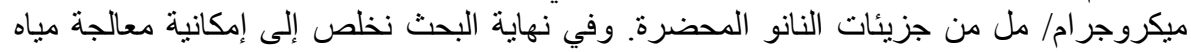

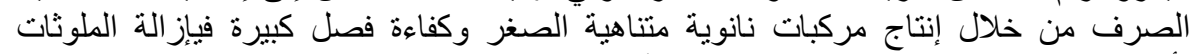
بأنو اعها المختلفة وتكلفة إقتصادية صغيرة جدًا بالمقارنة بمحطات معالجة الصرف الصنات الصحى حاليًا.

Egyptian J. Desert Res., 68, No. 1, 15-36 (2018) 